Jan P. Hudzik

Uniwersytet Marii Curie-Skłodowskiej w Lublinie

\title{
Krytyczna teoria polityki - portret zwielokrotniony
}

\section{Critical Theory of Politics - Multiplied Portrait}

\begin{abstract}
The article aim is to answer the question, what is the critical theory of politics? The author presents the historical and genealogical conditions of this approach, and relation to social critical theory - mainly the Habermas concept. This is a question about a theory that denounces the role of discourses - linguistic ways of capturing reality. What is the transcendental nature of such a theory, capable to release political subjects from feeling helpless and injustice? Answers to these questions are to be included in the portraits of the two types of critical theoretician of politics - the stabilizer and the exile.
\end{abstract}

Keywords: theory, critical theory of politics, critic-stabilizer, critic-exile, quasi-transcendental theory, universality of theory

\section{Wprowadzenie}

Co to jest krytyczna teoria polityki? Historycznie i genealogicznie łatwo ją zidentyfikować. Jej źródła sięgają społecznej teorii krytycznej rozwijanej przez szkołę frankfurcką, inspirowaną marksizmem. Jest wyrazem emancypacyjnych ambicji, jakie zachodnia lewica intelektualna wiąże z naukami społecznymi. Ambicje te niepodzielnie kultywują kolejne jej pokolenia, które mniej więcej od lat 60. minionego wieku zdążyły już dokonać tzw. zwrotu politycznego w szeroko pojętej humanistyce, w którego wyniku teoria została potraktowana jako rodzaj dyskursu i praktyki społecznej. Teoria polityki w tej wersji rozlała się więc niejako na teorię humanistyczną w ogóle, jest aspektem i komponentem badań teoretycznych nad literaturą, historią, mediami, popkulturą, społeczno-kulturową tożsamością płci czy nad miastem. Nie to jednak jest przedmiotem niniejszych rozważań. Koncentrują się one na merytorycznej stronie zagadnie- 
nia - bardziej już skomplikowanej. Mogą bowiem pojawić się wątpliwości, czy predykat „krytyczna” w odniesieniu do teorii ma oznaczać tylko to, że mówi ona samą prawdę i tylko prawdę o rzeczywistości społeczno-politycznej. Gdyby jednak takie znaczenie przypisać podejściu krytycznemu, to wyrażenie „krytyczna teoria polityki" straciłoby rację bytu, ponieważ każda teoria społeczna jest w tym sensie krytyczna, zakłada pewien zasób wiedzy - idei, norm, twierdzeń - spekulatywnej, który nawet jeśli nie pokrywa się z doświadczeniem, to stanowi model lub wskazówkę dla niego, służący do naprawy sytuacji konkretnych podmiotów społecznych. Zakłada się tutaj, wprost lub nie wprost, że teoria ma bezpośredni wgląd w prawdziwszą prawdę o nich. Czy jednak zawsze chodzi jej wtedy o ich emancypację? O ujawnianie przekłamań i mitów na ich temat, które krępują ich w zastygłych, prawem usankcjonowanych relacjach władzy, dominacji i podległości? Chyba nie, wydaje się, że częściej teorii zależy na legitymizowaniu status quo i traktowaniu go jako (jedynie) właściwego przedmiotu specyficznie teoriopolitycznego sposobu przedstawiania świata. Dlaczego tak się dzieje? Czy możliwe jest inne krytyczne teoretyzowanie na temat polityki? Jeśli tak, to jak należałoby rozumieć jego uniwersalność, a więc także i naukowość, która potrafiłaby sprzeciwić się hegemonicznemu podmiotowi politycznemu, jakim jest państwo, i podważyć fundamenty jego instytucjonalnej stabilności? Jest to pytanie o teorię, która demaskuje umowność tych fundamentów jako dyskursów, językowych sposobów ujmowania rzeczywistości - historycznych, ideologicznych, ekonomicznych, militarnych, medycznych i in. Czym miałaby być wobec tego jej transcendentalność - ów aprioryczny zasób wiedzy, który nadawałby jej siłę (o gwarancji zapewne nie ma tu mowy) do wyzwalania podmiotów politycznych z poczucia bezsilności i niesprawiedliwości?

Żeby poradzić sobie z tymi niejasnościami, portretuję i analizuję poniżej dwa typy krytycznego teoretyka polityki - jako stabilizatora oraz jako wygnańca. Próbuję pokazać ich adaptacje w autentycznej praktyce dyskursywnej - po przykłady sięgam do niemieckiego i polskiego dyskursu politycznego.

\section{Teoria (krytyczna)}

Tym, co miałoby wyróżniać teoretyka od innych badaczy społecznych - zdaniem konserwatywnego filozofa, Michaela Oakeshotta - ,jest nieustanne zainteresowanie owym bezwarunkowym, krytycznym zaangażowaniem rozumienia, w którym każde rozumienie (czy to «fakt», czy «teoremat») rozpoznaje się jako jeszcze-nie-zrozumiane, a zatem jako zaproszenie do zrozumienia" (Oakeshott, 2008, s. 12-13). Teoretyzowanie wiąże się zatem z samonapędzającym się mechanizmem - z zaangażowaniem samego rozumienia, które od- 
nosi się zawsze do pewnych zastanych już rezultatów rozumienia: „faktów” i „teorematów” - i odbiera je jako niewystarczające, czyni je obiektem kolejnego namysłu krytycznego, każe pytać o to, co się tu naprawdę dzieje. Nie ma więc teoretyzowania innego niż krytyczne. „Teoria krytyczna” to wyrażenie redundantne.

Teoretyzowanie na temat społeczeństwa i polityki jest procesem mentalno-działaniowym o strukturze kolistej (Hudzik, 2017), polega na odchodzeniu od punktu wyjścia - zastanego stanu rzeczy społecznych w istniejących ramach ich zrozumiałości - oraz na dochodzeniu do niego już w innej fazie jego rozpoznania. Zakłada się tutaj, że konkretne aktywności teoretyczne, polegające na operowaniu abstrakcyjnymi, mentalnymi konstrukcjami ingerują w rzeczywistość społeczną i stwarzają przez to pewien problem dla tych samych (i kolejnych) teoretyków, a przy okazji także dla wszystkich innych osób, do których przymierzane są te konstrukcje. Nie może być zatem mowy o teoretyzowaniu jako praktyce aksjologicznie neutralnej, jest ono bowiem aktem indywidualnym, który ma implikacje moralne, wiąże się przecież zawsze z pewnym ryzykiem ubezwłasnowolnienia innych, podejmowania za nich decyzji. Ale zarazem jest też przedsięwzięciem zbiorowym, opartym na społecznym autorytecie nauki, ma implikacje polityczne: dotyczy ludzi uwikłanych w określone relacje władzy, panowania i dominowania.

Mamy tu więc do czynienia z pewnym osobowym lub osobistym zaangażowaniem, $\mathrm{z}$ ryzykiem, jakie niesie $\mathrm{z}$ sobą praca, która nie jest moralnie obojętna dla jej wykonawców, a co zatem wiąże się (postulatywnie) z ich ograniczonymi roszczeniami do obiektywizmu, bezstronnego wyjaśnienia badanych zjawisk. $\mathrm{Z}$ założenia tak rozumiane teoretyzowanie jest typem praktyki społecznej, która nie mieści się w pojęciu aktywności naukowej w pozytywistycznym tego słowa znaczeniu. Badania w sensie Geisteswissenschaften i filozoficzna analiza kultury, którą uprawiali swego czasu twórcy społecznej teorii krytycznej, Theodor Adorno i Max Horkheimer, są z tej perspektywy postrzegane jako nienaukowe artykulacje osobistych nastrojów i upodobań, nic więcej jak tylko propaganda polityczna uprawiana za pomocą metod nauk społecznych (MacDonald, 2012, s. 321-325). Takie oskarżenia ani nie dotykają, ani nie zmieniają krytycznej teorii społecznej, wynikają raczej z nieporozumienia - intencjonalnie nie chce ona być bowiem naukowa w scjentystycznym tego słowa znaczeniu, co więcej, w ogóle zależy jej na tym, by wymykać się wszelkim esencjalistycznym kategoryzacjom. Z założenia ma być konstruktem nieustabilizowanym i nieokreślonym zarówno pod względem ontologicznym, jak i metodologicznym, i pozostawać w nieustannym ruchu: nie może dać się zatrzymać, pozwolić na résumé, na wypełnienie aktualną treścią używanych form uniwersalności, lub - inaczej mówiąc - na zamknięcie, podsumowanie swoich wyników poznawczych w postaci 
„faktów” i „teorematów". Z teorią krytyczną mamy do czynienia o tyle, o ile stanowi ona sama dla siebie wyzwanie, budzi niezgodę i opór aktorów społecznych, do których się odnosi, oraz samych badaczy. O ile napotyka na bariery zarówno osobowościowe, jak i polityczne - chodzi przecież o zaangażowanie jednych i drugich, ich nieobojętność wobec aktualnego stanu rzeczy społecznych: nierówności i niesprawiedliwości. O ile jej wykonawcy pozostają pod pręgierzem krytyki, tak samo jak i poddana ich interwencjom rzeczywistość społeczna. Ani teoretykom krytykom, ani społeczeństwu, w którym są oni aktywni, nigdy nie udaje się w rezultacie być w pełni sobą, ustanowić siebie jako obiektywnej rzeczywistości (Laclau, Mouffe, 2007, s. 137).

\section{Krytyczna teoria polityki}

$\mathrm{Na}$ tym polega fenomen teoretyzowania, krytycznego zaangażowania, w rzeczywistości niezależnie od tego, czy jego autorami są osoby o poglądach konserwatywnych (jak zacytowany na wstępie Oakeshott), czy lewicowych. Tak przynajmniej sprawa wygląda na poziomie teorii, a może raczej: metateorii. Ale to tylko pewna idealizacja, jeśli pozostać przy dualistycznym myśleniu według opozycji myśl-rzeczywistość, język-fakty. Takie myślenie przestaje tu jednak obowiązywać. Mówimy o teorii, której nie da się oderwać od praktyki społecznej i wspiąć na jakiś wyimaginowany poziom meta. Praktyka teoretyczna to sformułowanie, które najlepiej odpowiada, nazwijmy to najogólniej, nie-pozytywistycznemu rozumieniu teorii polityki. Zakłada ono, że teoretyczne badania krytyczne zamieniają problemy poznawcze na problemy praktyczne, odnoszą się do siebie samych i zarazem są konieczne „do bieżącej regulacji życia społecznego". Ta regulacja praktyczna - jak zapewnia dalej James Bohman, jeden ze współczesnych teoretyków amerykańskich - „zawiera normy rządzące samą krytyczną nauką społeczną”. I jeszcze dodaje: „Refleksyjne praktyki nie mogą pozostać takie bez krytycznego badania społecznego, a krytyczne badanie społeczne może być sprawdzone tylko w takich praktykach" (Bohman, 2003, s. 107). W odniesieniu do teorii politycznej mówi się w związku z tym - a to już opinia innej amerykańskiej badaczki, Ruth W. Grant - że jest ona „przedłużeniem naturalnej, codziennej działalności”, że teoria polityczna wkracza i zagłębia się w istniejące reżymy konceptualne, w ich wartości, źródła, transformacje, tym samym wiąże się z koncepcjami legitymacyjnymi - „ograniczeniami narzucanymi na dającą się zaakceptować sferę publiczną" - oraz sposobami interpretowania ludzkich działań. Grant konkluduje: „Jeśli polityka sama zawiera w sobie teorię polityczną, to badanie polityki musi zawierać teorię polityczną" (Grant, 2004, s. 185). 
Spróbujmy wyprowadzić stąd pewne konkretne wnioski dla teorii polityki jako teorii krytycznej. Otóż metodologiczne powiązanie krytycznej (auto)refleksji z regulacją życia społecznego oznacza, że teoria nie odnosi się do żadnego odrębnego, transcendentnego wobec niej dyskursu, rozumianego jako jakiś niezależny od niej język, zespół idei, wartości i twierdzeń traktowany jako gotowy wzorzec dla praktyki. Taką transcendentalną koncepcją mogłoby być na przykład żądanie, żeby rezultaty badań były rozstrzygane na drodze rozumowania dyskursywnego przeprowadzonego przez neutralnych, zewnętrznych obserwatorów. Roszczenie to jest absurdalne w opisywanej sytuacji, w której zarówno sami teoretycy, jak i ludzie objęci ich namysłem są stronniczy - wyjaśnienie ich problemów staje się komponentem sposobu, w jaki oni sami je rozumieją. Ani teorii, ani społeczeństwa nie daje się więc uzasadnić czysto dyskursywnie, teoretycznie, wchodzą tu bowiem zawsze w grę motywy polityczne i etyczne (Tugendhat, 2004, s. 177-180). Abstrakcyjna myśl w postaci zestawów faktów i twierdzeń, czyli pewnych systemów wiedzy, zawsze jest w ruchu, zatacza kręgi w powtarzalnych i performatywnych aktach mówienia i działania, polegających na wypełnianiu abstrakcji konkretną treścią.

Teoretyk narażony jest zazwyczaj na wiele pokus związanych z wyrwaniem się poza to błędne koło niespełnienia i znalezieniem wreszcie dla siebie stabilnego punktu obserwacyjnego, który pozwoli mu na dystans i obiektywizm wobec badanych zjawisk, a przy okazji też zapewni spokojne i dostatnie życie. Rzecz w tym, że to wszystko może on osiągnąć tylko za cenę legitymizowania społeczno-politycznego status quo - pracując dla instytucji państwowych, ma oczywiście wobec nich pewne zobowiązania. Jak tłumaczy Andrzej W. Jabłoński, „[i]nstytucje jako struktury władzy i wpływu mają autonomiczną zdolność wpływania na zachowania aktorów politycznych, łącznie z tymi, którzy je tworzą" (Jabłoński, 2017, s. 112). Ten wpływ dokonuje się za sprawą reguł, norm i wartości, na których podstawie instytucje funkcjonują: motywują aktorów i swoich członków do działania, określają ich role społeczne i zawodowe oraz zakres ich działań społecznie akceptowanych. Przez stosowne selekcjonowanie - włączanie i wykluczanie - wszystkich tych treści instytucje zakreślają jednak przede wszystkim pole/ramy/terytorium tego, co państwowe, polityczne, sprawiedliwe, ale także i tego, co naukowe. Skoro przede wszystkim w interesie państwa leży stabilność jego porządku społeczno-politycznego, to naturalnie przejmuje ono inicjatywę w zagospodarowaniu, czyli wypełnieniu konkretną treścią, tych ogólnych pojęć, form uniwersalności, na których zbudowane są mechanizmy instytucjonalne. Państwo stabilizuje więc ich znaczenia w swoim systemie jurydycznym i politycznym, dzięki czemu zyskują one status obiektywnych rzeczywistości. Jeśli badania naukowe - a te nas tu głównie interesują - odpowiadają instytucjonalnym kryteriom naukowości, prawdziwości i obiektywności, to 
oczywiście one również legitymizują system polityczny i zapewniają swoim wykonawcom bezpieczeństwo: etat na uczelni, karierę i prestiż. Trudno się zatem dziwić, że lojalność wobec władzy politycznej zwykle, w znanej nam historii nauki, wygrywa z lojalnością wobec samego teoretyzowania. To ostatnie wymaga zdolności i woli brania udziału w publicznej grze, czasem wręcz w bitwie, o dominację/hegemonię na polu wypełniania partykularną treścią wymienionych wyżej uniwersalnych form, wybiegania z nimi poza horyzont teraźniejszości, otwierania ich na przyszłość, wprowadzania do nich ciągle nowych elementów, różnic, których one dotąd swym zakresem nie obejmowały. Dlatego teoretyzowanie to niekończący się proces - jego każdorazowy finał, w postaci instytucjonalnie ustalonych zespołów faktów i twierdzeń, jest początkiem podważania ich prawdziwości, a co za tym idzie, destabilizowania także istniejącego systemu urządzeń i praktyk instytucjonalnych.

Od krytycznego teoretyka społecznego oczekuje się więc czegoś, co narusza panujący porządek rzeczy (społecznych) i co nie jest przez to na rękę władzy politycznej, rozciągającej się także na podległe jej instytucje nauki. Krytykowi chodzi o ujawnienie i zdemaskowanie nieobecności źródła, jakiejś fundamentalnej prawdy faktów, nadającej sens zewnętrznym obrazom świata, $w$ tym także obowiązującym regułom gry politycznej, jako naturalnym i oczywistym. $Z$ tego powodu musi on być niebezpieczny dla władzy politycznej. Inaczej podchodzą do tego jego niekrytyczni, w rzeczy samej „naukowi”, koledzy teoretycy, którzy akceptują zastany porządek społeczny i tworzące go relacje władzy. Czynią to już na etapie przyjęcia określonych sposobów badania owego porządku, uznanych (instytucjonalnie) za metodologicznie jedynie poprawne. Wymowa tego gestu jest jednak znacznie szersza - oznacza on mianowicie także dostosowanie się teoretyków do porządku społecznego akceptowanego jako fragment naturalnego porządku rzeczy. W tych warunkach ich postawa „krytyczna” - a z tej etykiety na ogół uczeni nie chcą rezygnować, ponieważ nadaje im ona nadal rangę naukowości - staje się już tylko hipokrytyczna: wyraża się zaledwie w samej retoryce, albo w stylu życia, który znajduje akceptację w sferze publicznej. Dla rasowego demaskatora takich zachowań, Maxa Horkheimera, oznaczają one nic innego, jak tylko „bierne uczestnictwo w podtrzymywaniu powszechnej niesprawiedliwości” (cyt. za: MacDonald, 2012, s. 320).

\section{Problem uniwersalności}

W poszukiwaniu historycznych źródeł społecznej teorii krytycznej wskazuje się Karola Marksa, który w odniesieniu do kategorii pracy w Zarysie krytyki ekonomii politycznej pisze między innymi, że 
[...] najbardziej nawet abstrakcyjne kategorie, chociaż właściwe są - właśnie dzięki swej abstrakcyjności - wszystkim epokom, to jednak w samej określoności tej abstrakcji są w równej mierze wytworem historycznych stosunków i posiadają swe pełne znaczenie tylko dla tych stosunków i w ich obrębie (cyt. za: Habermas, 2002, s. 725).

To klasyczny problem uniwersaliów w wersji nowoczesnej: ogólne pojęcia, formy uniwersalności są wytworem określonych historycznie stosunków społecznych i każda wypowiedź odwołująca się do tego, co uniwersalne, ma $\mathrm{z}$ góry przypisane pełne znaczenie, czyli wypełnienie $\mathrm{w}$ postaci przygodnych, historycznych treści. Jak to możliwe? Co ze znaczeniami wypowiedzi, sformułowanych przy użyciu abstrakcyjnych pojęć, których nie da się do końca przewidzieć, które odnoszą się do zjawisk wychodzących poza dotychczasowe granice tych pojęć? Jak można pogodzić to, co uniwersalne, z każdorazowo innym, partykularnym? Pytania te zmierzają do jednego: Jak zaangażowany moralnie i politycznie krytyk może być mimo wszystko w swych badaniach uniwersalny, ahistoryczny?

Odpowiedź Marksa prima vista jest prosta: w tym, co abstrakcyjne/uniwersalne znajduje się to, co poszczególne. Ale to niewiele nam mówi, dalej bowiem musimy pytać, w jakim sensie „się znajduje”. Czy to jest problem ontologiczny, czy epistemologiczny? Czy trzeba tu uruchomić wyobraźnię platońską i wprowadzić na przykład kategorie partycypacji, to jest uczestnictwa lub ucieleśnienia, czy wystarczy mówić o jakichś genetycznych, strukturalnych, funkcjonalnych albo komunikacyjnych zależnościach między abstrakcją a konkretem? Inaczej, czy mowa tu o prawdziwości - w cytacie jest to „określoność abstrakcji” - jako wierności faktom, czy o adekwatności ich przedstawiania w kategoriach określonych teorii społecznych, takich jak na przykład ewolucjonizm, funkcjonalizm czy strukturalizm? W nowoczesnym, postmetafizycznym świecie, o którym pisze Marks, w grę wchodzi głównie to drugie rozwiązanie, zgodnie z którym ustalane przez abstrakcyjne kategorie fakty i twierdzenia nie są ściśle ogólne, lecz jedynie numerycznie ogólne - mowa tu o zjawiskach i przedmiotach tylko do siebie podobnych, analogicznych, nigdy zaś z sobą identycznych (Buksiński, 2001, s. 96-97). Analogia dotyczy nie esencjalnych właściwości rzeczy bądź faktów (te przecież musiałyby być dostępne tylko dla uprzywilejowanych badaczy), lecz ich właściwości poznawczych, czyli po prostu ich znaczeń, przedstawień, reprezentacji kulturowych - naukowych, religijnych, artystycznych czy ideologicznych. Dzięki temu przejściu z samego bytu do wiedzy o nim (w filozofii mówi się tu o zwrocie nominalistycznym) abstrakcja może spotykać się z konkretem - oddawać jego „pełne znaczenie”. Przy takim rozwiązaniu nadal jednak otwarte pozostają dwa pytania. Pierwsze: Czym ma być to pełne znacze- 
nie? Drugie: Czy rzeczywiście każdy, w dowolnym czasie, może do niego dotrzeć? Obydwa te problemy związane są z nadrzędnym wobec nich problemem transcendentalności teorii.

\section{Habermas: krytyka i kryzys}

Na podstawie tego, co zostało powiedziane wyżej o teorii krytycznej, trzeba by przyjąć, że każdy kompetentny członek społeczeństwa, czyli taki, który wykazuje umiejętności praktycznego uczestnictwa w działalności społecznej, byłby także od razu doświadczonym krytykiem teoretykiem społecznym. Wolno tak przypuszczać, skoro taki sam wniosek w odniesieniu do socjologa wysnuwa na przykład sam Anthony Giddens (2003, s. 65). Ale to oczywiście założenie fałszywe. Wiedza i refleksyjne nastawienie teoretyka nie pokrywają się przecież $\mathrm{z}$ wiedzą i nastawieniem zwykłego, refleksyjnego aktora społecznego, zorientowanego w konwencjach społecznych, znającego siebie i innych ludzi. Skoro tak, to pojawia się problem transcendentalności teorii jako rodzaju wiedzy elitarnej i ekskluzywnej, niezależnej od empirii - korporacja teoretyków nigdy nie uwolniła się od tego rodzaju przekonań, odpowiadających zresztą także potocznym wyobrażeniom na ten temat, respektującym zasady podziału ról społecznych oraz uznającym prestiż instytucji naukowych. Jak to więc właściwie jest? Problem wygląda na kwadraturę koła: teoria już zawsze zawarta jest $\mathrm{w}$ praktyce, przy czym jednocześnie ciągle spotyka się z oczekiwaniami bycia wobec niej czymś zewnętrznym, jakimś dla niej wskaźnikiem lub drogowskazem. Spróbujmy rozwikłać tę aporię.

Zatrzymajmy się w tym celu na chwilę nad rozwiązaniem, które proponuje Jürgen Habermas. On także, podobnie jak jego nauczyciele, Marks czy Horkheimer, zakłada, że:

[...] krytyczna teoria społeczeństwa zdaje sobie sprawę z faktu, iż to, co robi, odnosi się też do niej samej; wie, iż poprzez akty poznania również przynależy do obiektywnej całości życiowych związków, którą zamierza uchwycić. Teoria nie pozostaje zewnętrzna w stosunku do kontekstu swego powstania, włącza go ona w siebie na drodze refleksji. [...] To samo odnosi się do kontekstu zastosowania" (Habermas, 2002, s. 722).

Teoria krytyczna nie jest zewnętrzna w stosunku do kontekstów swego powstania i zastosowania - zawsze musi być zmediowana przez perspektywę każdorazowo napotkanych aktorów społecznych (Brunkhorst, 2014, s. 82-83). Jakże więc ma ona dotrzeć do „obiektywnej całości życiowych związków”, w które 
uwikłany jest teoretyk tak samo jak i zwykli refleksyjni ludzie, świadomi tego, co czynią?

W rozwiązaniu tego problemu Habermas nie widzi innej możliwości, jak tylko zastosować argumentację quasi-transcendentalną. Zakłada on mianowicie, że kwestie poddane pod debatę publiczną (chodzi o reguły dotyczące wspólnego działania ludzi) powinny być rozstrzygane przez całkowity konsens polityczny (to kontrfaktyczna idealizacja, niezależna od kontekstu powstania i zastosowania teorii), przy czym jednocześnie powinny następować $\mathrm{w}$ określonym środowisku, w drodze kompromisu i decyzji kolektywnej (warunek empiryczny). Pisze między innymi tak:

Teoria społeczna, która domaga się uznania uniwersalności swych podstawowych pojęć, nie mogąc w prosty sposób na zasadzie konwencji przystawić ich do swego przedmiotu, pozostaje w okowach relacji samo-odniesienia, co Marks zademonstrował na przykładzie pojęcia pracy abstrakcyjnej (Habermas, 2002, s. 724).

Chodzi o to, żeby praca abstrakcyjna odnosiła się sama do siebie i potrafiła jednocześnie przystawić się do przedmiotu - materii społecznej. Nie dzieje się to automatycznie, na zasadzie konwencji. $\mathrm{W}$ takim razie - ponawiamy pytanie - kiedy abstrakcji udaje się oddać „pełne znaczenie” konkretu? Odpowiedź niemieckiego teoretyka brzmi następująco: wtedy mianowicie, kiedy ów konkret, czyli określona sytuacja w ludzkim świecie życia, znajdzie się w stanie kryzysu, kiedy ów świat ulegnie zaburzeniu i stanie się dla swoich mieszkańców w całości problematyczny (Habermas, 2002, s. 721-722, podkr. tu i dalej za oryg.).

Przypomnę tylko krótko (rezygnując z dalszych rozbudowanych wyjaśnień), że Habermas odróżnia „świat życia” (niem. Lebenswelt), to znaczy świat przeżywany przez nas prywatnie (sfera prywatna) i publicznie (sfera publiczna), w którym z sobą rozmawiamy, dialogujemy, oraz system, w którym dominują działania celowo racjonalne - a to jest gospodarka (rynek) i państwo - regulowane za pośrednictwem pieniądza i władzy. Wracam do sytuacji, w której ludzki „świat życia" staje się w całości problematyczny. Otóż chodzi tu nie o całość jako totalność empiryczno-przedmiotową, niezależną od ludzkiej świadomości, lecz o totalność świata ograniczonego przez ludzką świadomość, lub - jak nazwie to Habermas - o „całość wiedzy stanowiącej nietematyzowane zaplecze i mającej konstytutywne znaczenie dla konstrukcji świata życia" (Habermas, 2002, s. 721). Taka całość w normalnych warunkach niedostępna jest ani badaczowi społecznemu, ani zamieszkującym ten świat ludziom. To dopiero wtedy gdy ów świat ulegnie jakiemuś radykalnemu zachwianiu, jawi się on poznającemu spojrzeniu jako totalność - tylko wtedy można zdystansować się do społeczeństwa jako całości i do krytykowania go. Ale uwaga: opisana tu akcja rozgrywa się w rzeczy- 
wistości społecznej wymykającej się ludzkim interwencjom. Nie zachodzi ona ani w warunkach laboratoryjnych, ani w gabinetach uniwersyteckich, i na jej intencjonalne sprokurowanie przez krytyków teoretyków społecznych nie ma co liczyć: „To sam rozwój społeczny musi doprowadzić do pojawienia się jakichś problematycznych sytuacji, które żyjącym w tym czasie ludziom obiektywnie otwierają uprzywilejowany dostęp do ogólnych struktur ich świata życia" (Habermas, 2002, s. 725).

Dopiero zatem wstrząs, kryzys w rozwoju społecznym otwiera ludziom „uprzywilejowany dostęp" do tego, co uniwersalne w ich przygodnym, życiowym otoczeniu. Gdyby jednak nawet zgodzić się na takie dziejowe rozwiązanie i powierzyć losy nauki niezależnemu od niej, transcendentnemu wobec niej, rozwojowi społecznemu, to nie zmienia to podstawowej wątpliwości, czy naprawdę abstrakcyjność podstawowych pojęć teorii zdoła odsłonić, ujawnić, pełne znaczenie świata wraz z jego „nietematyzowanym zapleczem”. Chodzi tu przecież o to wszystko, co w unikatowym położeniu ludzi niekomunikowalne, na nazwanie czego nie mają oni stosownego języka, a z czym muszą się borykać, a teoretyk/krytyk musi się zmierzyć. Ta fundamentalna wątpliwość przylgnęła do teorii krytycznej na dobre - to efekt jej nieubłaganej, kolistej struktury, okowów samo-odniesienia. Transcendentalne czy quasi-transcendentalne rozwiązania, mające w pewien sposób przybliżyć ją do nauki w jej pozytywistycznym znaczeniu, jedynie pogłębiają niepewność w tej mierze.

\section{Teoretyk stabilizator}

Teoria krytyczna, o której tu mowa, rzuca podejrzenie na wszelkie prawdy na temat świata społecznego, które roszczą sobie pretensje do powszechnej ważności. Mają go one zafałszowywać, homogenizując go, sprowadzając do jakiejś jednej zasady organizacyjnej (MacDonald, 2012, s. 333). To samo podejrzenie pada także na „praktyczną prawdę" (Habermas, 2002, s. 725) logiki działania komunikacyjnego, czyli dyskursywnych sposobów ustalania reguł życia społecznego, na które powoływał się Habermas. „Nieprzymuszony przymus” lepszego argumentu, który prowadzić ma według niego do powszechnego konsensusu w dyskursie publicznym, w rzeczywistym żywym sporze spotyka się więc także $\mathrm{z}$ (podszytą psychoanalizą) demaskacją jego nieświadomych źródeł, z oskarżeniem o „skryty jakobinizm liberalny”, żerujący na powszechnych, pospolitych emocjach - „, na resentymencie oraz pragnieniu bycia lepszym” (Sloterdijk, 2012, s. 64). Poczucie bycia lepszym, jak to samo wyjaśniają z kolei teoretycy komunikacji, wiąże się z byciem poprawnym politycznie (jakże więc zatem „krytycznym”?!), zawsze odwołującym się w rozmowach tylko do kon- 
sensualnie ustalonych znaczeń słów i unikającym przez to wieloznaczności. Zawsze zatroskanym o porozumienie, do którego może prowadzić tylko rozmowa „wolna od panowania i przemocy” (herschaftsfrei). A przecież w codziennej komunikacji nieustannie nastawieni jesteśmy na niepowodzenie, na zranienia przez użycie słów/języka, których/którego znaczenie w odbiorze rozmówcy wychodzi poza nasze (mówiącego) intencje (Butler, 2010, s. 103). Idealizujące założenie konsensusu daje krytykowi poczucie wyższości, a przy okazji jego wolne od przemocy działanie budzi też szacunek i uznanie instytucji państwa demokratycznego, którym zależy na ukazywaniu trwałości własnych fundamentów.

Czy da się uniknąć takiej krytyki krytyki? Chyba nie. Jak powiedziano, zawsze wiąże się ona przecież z pewnym ryzykiem, zawsze też jest stronnicza. I to niezależnie od tego, z której strony sceny politycznej jest prowadzona. Sprawdźmy ten mechanizm, pozostając nadal na terenie niemieckiego dyskursu politycznego. Przykład tym razem $z$ debaty publicznej w Niemczech, nawiedzonych - kulminacja: wrzesień-październik 2015 roku - przez falę uchodźców głównie ze zdestabilizowanych, ogarniętych działaniami wojennymi krajów Afryki Północnej, imigracji największej w historii tego kraju i zapewne największej w Europie od końca II wojny światowej. W prawicowej „Frankfurter Algemeine Zeitung" pisze Jörg Baberowski, historyk i teoretyk polityki na Uniwersytecie Humboldta w Berlinie:

Niemcy są krajem gotowym do niesienia pomocy i gościnnym. Są one też krajem, w którym ludzie różnych języków i kultur wzajemnie dobrze sobie radzą. Ale ten pokój staje się zagrożony, jeśli moralność i cnota są jedynymi źródłami, z których płyną uzasadnienia dla działania politycznego. W opinii publicznej mówi się tylko o uchodźcach, a nie o nielegalnych imigrantach. Uchodźca jest prześladowany. O nim można mówić tylko dobrze. Dobrze wiedzą o tym ci, którzy decydują o użyciu tego słowa. Imigrant może jednak mieć także inne motywy niż ucieczka. O nim nie mówi się jednak, ponieważ jego pragnienie imigrowania nasuwa pytanie, czy ktoś chce je zaspokoić. Zarzuty są jednak zakazane w krainie marzeń [im Reich] strażników cnoty, w którą w międzyczasie przemieniło Niemcy wiele mediów i polityków. Ten, kto wytyka to, że zadaniem polityki jest kierowanie się tym, co jest możliwe do zrobienia, a nie tym, co jest sprawą życzeń, musi się w najgorszym razie zgodzić na zarzut, że jest „na prawo” i dlatego w publicznym dyskursie nie może brać udziału. Natomiast religię, płeć i kulturę wywołuje duch czasu, który zamieszkuje światłe Niemcy, [i] chce, żeby wszyscy mówili tylko swoim własnym językiem. Jednak od oświecenia, które obywatel miał bronić przed władzą, od kwestii społecznej, która musiała być jego interesem, dawno on się już odwrócił. Nie chodzi już o to, co ktoś mówi, lecz o to, kto to mówi i w jakim języku jest to deklamowane (Baberowski, 2015a). 
Artykuł wzbudził gwałtowne reakcje, pojawiły się między innymi głosy, że jego autor „nie jest żadnym naukowcem, lecz prawicowym ideologiem” (Dreier, 2015). Pomińmy jednak ten wątek. Przyjrzyjmy się samej mechanice gry/zmagań o uniwersalność. Baberowski, choć sam nie jest uprawniony do przemawiania z pozycji uniwersalnej, zdaje sobie sprawę ze swoich ograniczeń, powiada przecież w ostatnim zdaniu, że nie jest tym „kimś”, z kim (w domyśle) liczy się dominująca („duch czasu”) opinia publiczna - rości sobie mimo to takie prawo. Sam jest więc kimś nieokreślonym, zajmuje chwiejną pozycję - jest i nie jest zarazem uprawniony. Ale jego chwiejność zdaje się jednak tylko retoryczną maską. Mamy tu do czynienia ostatecznie z silnym podmiotem - aktorem/teoretykiem politycznym, który mówi o uniwersalnym, substancjalnym podziale sceny politycznej na prawicę i lewicę, i stosuje chwyty perswazyjne, które pozwalają mu wyprodukować (skonstruować) współmyślącego $\mathrm{z}$ nim odbiorcę. Jednym $\mathrm{z}$ takich chwytów jest przekazywanie wspólnego, uniwersalnego systemu wartości za pomocą pojęć, które ze względu na swoją abstrakcyjność i pozytywne konotacje mogą liczyć tylko na przychylny odbiór: „Niemcy są krajem gotowym do niesienia pomocy i gościnnym" (Land der Hilfsbereitschaft und Gastfreundschaft). Na podobnie przychylny odbiór może liczyć także deklaracja bycia po stronie słabszych i prześladowanych: ci „na lewo" są silniejsi, mają po swojej stronie media i polityków, narzucają język debaty publicznej (znaczeń słów „uchodźca” i „imigrant”) i zakazują tym „na prawo” udziału w tej debacie. Drugi zastosowany w cytowanym tekście chwyt retoryczny, służący stworzeniu dogodnego/ uniwersalnego odbiorcy, polega na ironicznym zakwestionowaniu oczywistości (moralność i cnota polityki są zagrożeniem dla pokojowego współżycia ludzi) i przestawieniu znaków wartościowania opisywanych zjawisk: „strażnicy cnoty” to ci, którzy w istocie są przeciw „moralności i cnocie”, a „oświecone Niemcy” to pluralizm języków, religii, płci i kultur, w którym nie ma miejsca dla ludzi oświeconych, wolnością słowa cieszą się tylko uprzywilejowani, ci, którzy są blisko mainstreamowych mediów zbratanych $\mathrm{z}$ władzą polityczną.

Nie chodzi tu jednak o czystą perswazję i tropologiczny wymiar prezentowanego dyskursu politycznego. Analiza językoznawcza ma odsłonić mechanikę gry o hegemonię, o artykulację tego, co uniwersalne, a co za tym idzie, także o obnażanie praktyk wykluczenia i odrzucenia w świetle obowiązujących aktualnie konwencji uniwersalności. Istnienie tych konwencji, w przywołanym cytacie, ujawniają takie formuły, jak na przykład „w opinii publicznej mówi się...”, „dobrze wiedzą o tym ci, którzy decydują...” czy wreszcie „duch czasu”. Baberowskiemu chodzi o nowe wypełnienie tych pustych form uniwersalności. Mówi o „stabilizowaniu” (to jego słowo) społeczeństwa za pomocą języka, którego funkcja bynajmniej nie polega na „przedstawianiu” świata, lecz na jego ustanawianiu przez re-definiowanie pojęć Niemiec, tożsamości, władzy politycznej, 
prawa, wreszcie samych teoretyków polityki. Taka strategia komunikacyjna daje teoretykowi (por. Habermas, 2002) także poczucie wyższości: czuje się lepszy, ponieważ ma bezpośredni dostęp do prawdy, ma wiedzę niezależną od tego, co ludzie rzeczywiście myślą, i nie musi się z tym liczyć. W jednym $\mathrm{z}$ wywiadów powiada, że „nie może być [to] podstawą politycznych decyzji”. Teoretykowi krytykowi, stabilizatorowi społecznemu portretowanemu tutaj jako stabilizator chodzi więc o to, żeby to, co ludzie mają w głowach, mógł on zamienić na lepsze, „prawdziwsze” wersje. Mówi tak:

Myślę, że polityka musi kierować się tym, co jest możliwe do zrobienia. Jeśli sytuacja kryzysowa ludzi ma być jedynym powodem, który upoważnia do imigracji, to Niemcy musiałyby przyjmować każdego, kto opuszcza swój kraj i chce do nas przyjechać. Nie może to jednak być podstawą politycznych decyzji. Polityka powinna z wyczuciem postanawiać o tym, kto może imigrować, a kto nie. Wszystkie kraje imigranckie w ten sposób się zachowują, i przez to ustabilizowały swoje społeczeństwa. W Niemczech dzieje się właśnie przeciwnie, ponieważ to prawo azylanckie decyduje o tym, kto może przyjechać, a nie wola polityczna (Baberowski, 2015b).

Wraz z pojęciem woli politycznej Baberowski niebezpiecznie zbliża się do decyzjonizmu, stanowiska wiązanego $\mathrm{w}$ niemieckiej teorii politycznej przede wszystkim z Carlem Schmittem. Decyzjonizm traktuje państwo jako polityczną jedność ustanawiającą porządek społeczny, w którym poszczególne jednostki są czymś przypadkowym. Odpowiednio mamy tu więc również do czynienia z krytyką, która oskarża i demaskuje zastaną rzeczywistość na podstawie bezpośredniego wglądu w konieczne i ostateczne prawdy na jej temat. Krytyk stabilizator, niezależnie od tego, czy jego barwy są prawicowe, czy lewicowe, dysponuje „prawdziwszymi”, bardziej naturalnymi wersjami tego, co ludzie na dany temat myślą, i totalizuje w ten sposób pole polityczności. Znaczenia użytych w cytowanych tekstach pojęć i figur retorycznych uznaje on za konstytutywne w odniesieniu do samej rzeczywistości politycznej, nie zaś do znaczeń, jakie ludzie jej przypisują. Intencja cytowanych tekstów, podobnie jak intencja ich autora, który zabiera głos w otwartej debacie publicznej, zdają się więc ostatecznie zmierzać do jej (tej debaty) zamknięcia. Gra toczy się o całkowite wypełnienie uniwersalności przygodną treścią. Stawką jest w niej, w wymiarze ontologicznym, esencjalizm (ujawnienie istotnych własności bytów politycznych), w wymiarze epistemologicznym natomiast - naturalizm, czyli przekonanie o bezpośrednim do nich dostępie, bez udziału reprezentacji kulturowych, zawartych na przykład $\mathrm{w}$ historii idei politycznych czy moralnych. Ale co to w rzeczywistości oznacza? To mianowicie, że krytyczna refleksja polityczna prowadzona $z$ takiej pozycji, wbrew pozorom (pomimo zastosowanej retoryki) bynajmniej nie stawia sobie za 
cel emancypacji konkretnych ludzi odczuwających krzywdę i niesprawiedliwość ze strony władz, które opuściły ich w stanie zagrożenia spowodowanego napływem imigrantów. Krytyce, o której tu mowa, bardziej - jak się wydaje - zależy na spektakularnym zwycięstwie $\mathrm{w}$ dyskursywnych zmaganiach o uniwersalność: na wykluczeniu pluralizmu interpretacji i stanowisk na temat tego, co polityczne, a co niepolityczne, co narodowe, a co nienarodowe, co rzeczywiste/ważne, a co nierzeczywiste/nieważne. Domaga się ona konsensusu, który powierza konstytuowanemu i wyobrażonemu przez siebie hegemonicznemu podmiotowi politycznemu, jakim jest państwo.

\section{Teoretyk wygnaniec}

Krytyk wzbudza niepokój i poczucie winy u hipokrytów deklarujących wartości, których sami w życiu nie przestrzegają. Ale i sam musi liczyć na wzajemność, uważność tych, których krytykuje. Nie może on wobec tego czekać z założonymi rękami na trzęsienie ziemi - na co dzień pracuje na rzecz ludzi, umacniając ich w przekonaniu o wolności wyboru, objaśniając im świat, tak żeby go zrozumieli. Czyni to wtedy, kiedy nie są oni świadomi (w kategoriach nauk społecznych) swojego położenia społecznego - takiego jak na przykład bieda, bezrobocie, migracje czy wykluczenie cywilizacyjne - bądź nie wiedzą, co mogą robić publicznie, nie znają skutków swoich działań, takich jak na przykład głosowanie czy udział w organizacjach społecznych. Krytyk - świadomy, że jego punkt widzenia pozbawiony jest uniwersalnej prawomocności zmierza do tego, żeby zapobiec ustabilizowaniu dyskursów i praktyk lokalnych, podporządkowaniu ich jakiemuś odgórnie, administracyjnie ustalonemu porządkowi. Łamie stare i tworzy nowe reguły. Wybierając ten ryzykowny fach, skazuje się na los wygnańca (Bauman, 2006, s. 320-321).

Gra o wypełnienie autentyczną treścią form uniwersalności stanowiących ramy zrozumiałości otaczającego świata, jak zostało to już powiedziane, jest rozgrywką o hegemonię, o „politykę prawdy”, która przenika do jurydycznych systemów władzy, do jej formuł legitymizacyjnych, do programów edukacyjnych itd. Każda spekulacja rodzi się na horyzoncie tak powstałych tekstów - wobec nich daje się ona uzasadnić, teksty te zaś stanowią warunek jej zaistnienia. O takim statusie transcendentalności poststrukturalista i postmarksista Ernesto Laclau tak oto pisze:

Pokusiłbym się o postawienie tezy, że wymiar transcendentalny jest czymś nieuniknionym, transcendentalność jednak, w pełnym znaczeniu tego słowa, jest czymś niemożliwym (dlatego mówić możemy jedynie o quasi-transcendentaliach). Skąd 
wynika owa niemożliwość? Stąd, że pełna transcendentalność wymagałaby już u samego początku wytyczenia wyraźnej linii demarkacyjnej oddzielającej ją od tego, co empiryczne, a to jest nieosiągalne. Nie ma obiektu bez transcendujących go warunków możliwości (oto nieprzekraczalny horyzont transcendentalny), wszelako zważywszy na to, że ów horyzont obejmuje nierozstrzygalne infrastruktury - takie jak iteracje, uzupełnienia, oznakowania itd. - empiryczny moment decyzji pozostaje w złożonym wewnętrzno/zewnętrznym związku z owym transcendentalnym horyzontem (Laclau, 2014, s. 94-95).

Quasi-transcendentalność teorii wiąże się więc z faktem, że standardy uniwersalności to zawsze tylko historyczne konwencje, sformułowania uwikłane w lokalne podziały społeczne i różnice interesów. Uniwersalność za każdym razem zakreślona jest przez bieżące imaginaria społeczne. Krytyczny teoretyk wydobywa na wierzch jej wykluczający charakter - na przykład ze sfery uniwersalności w różnym miejscu i czasie wykluczane były i nadal są kobiety czy mniejszości rasowe - i w ten sposób bierze udział w sporze o jej przyszłą postać. Zdemaskowane i zredefiniowane w jego pracy pojęcia, takie jak wolność czy sprawiedliwość, uzupełnione w swych znaczeniach o różnicę, konkretną treść, mogą w rezultacie przenikać do systemu jurydycznego i przybierać tam znaczenia, których wcześniej nie miały, obejmować nowe interesy i podmioty, które wcześniej były poza ich zasięgiem. W tym zdaje się tkwić cała tajemnica transcendentalności. Każdy moment orzekania/predykacji stwierdzającej (w cytacie: „empiryczny moment decyzji”) przypisuje danemu obiektowi właściwości uwarunkowane zastanymi praktykami i kontekstami językowymi oraz kulturowymi (to owe „nierozstrzygalne infrastruktury”), zawsze dokonuje się w ich obszarze. Każde orzekanie narzuci obiektowi inne/obce znaczenie, ale też i każde - zabierze mu coś z tego, co jego własne. Krytyk wygnaniec ma strzec różnicy przed przemocą. Zagrożenia dla niej upatruje on już na poziomie języka, a więc znacznie niższym niż ten, który odnajdujemy w ideologiach czy instytucjach państwowych.

W kreślonym portrecie teoretyka polityki jako krytyka wygnańca zakłada się, że wyciąga on wnioski $z$ tak zwanego zwrotu lingwistycznego w humanistyce i naukach społecznych, i przyjmuje się w rezultacie, że i on sam musi więc być świadomy tego, że również jego język dysponuje siłą przemocy symbolicznej, że i jego wypowiedzi zbudowane są ze zdań wykorzystujących pojęcia modalne, znane logikom wielowartościowym, spełniające pragmatyczne lub, szerzej, aksjologiczne kryteria prawdziwości. Te ostatnie mogą zatem wskazywać chociażby na zakres i siłę bez-przymusowej przemocy symbolicznej, którą stosuje sam krytyk: może ona być wroga, nieprzyjazna, agresywna, szczera, hipokrytyczna (kryteria społeczne i etyczne) bądź dosłowna lub metaforyczna (kryteria 
poznawcze), bądź indywidualna lub instytucjonalna, korzystna lub pożyteczna (kryteria prakseologiczne).

Opisaną świadomość metodologiczną krytyczna teoria polityki może zdobyć - i ją praktykować - w różnych paradygmatach badawczych: poststrukturalistycznym, psychoanalitycznym czy nawet neurobiologicznym. W tym ostatnim wariancie jej quasi-transcendentalny horyzont wyznaczony byłby przez podmiot integralny, ucieleśniony, empatyczny. Zakłada się tutaj, że

$\mathrm{Na}$ werbalne, wizualne, dźwiękowe i in. reprezentacje „polityki” narządy ludzkie uaktywniają swoje funkcje według tych samych zasad, co w przypadku słuchania muzyki, oglądania widowiska, dotykania jakichś rzeczy, odczuwania rozkoszy, przyjemności czy bólu, słowem - poprzez sensomotoryczne rozumienie docierających doń, egzystujących „poza plecami naszej świadomości” (Merleau-Ponty), sygnałów o określonej zawartości informacyjnej (Dziubka, 2017, s. 63).

Zaufanie w poznawczą wartość ludzkiego aparatu sensomotorycznego, otwarcie się na sferę doznań, najbardziej uniwersalną i najbardziej intymną zarazem, związaną z niekomunikowalnymi do końca doznaniami bólu, rozkoszy i przyjemności, jest wyrazem odwagi teoretyka. Odwagi, ale nie poczucia bycia lepszym, które, jak widzieliśmy, nie jest obce teoretykowi krytykowi sportretowanemu wyżej jako stabilizator (zob. Habermas, 2002; Baberowski, 2015a, 2015b). Odwaga wiąże się teraz z wyłamaniem się z konwencji badań behawioralnych, ilościowych, pozytywistycznych, ograniczających się tylko do tego, co da się zmierzyć i zważyć. Pociąga ona jednak za sobą także - nie retoryczną, nie pozorowaną - zgodę teoretyka na błądzenie i niepowodzenia, akceptację własnych niedoskonałości, a przy tym, mimo tego, pragnienie zmiany świata na lepsze. Tak nakreślona kondycja teoretyka wygnańca nie podlega żadnym ekskluzywnym standardom metodologicznym. Nie jest to sytuacja komfortowa. I może dzięki temu właśnie w praktyce badań teoretycznych górę bierze zwykle potrzeba ustalonej i ustabilizowanej pozycji (tożsamości) zawodowej badacza, w ramach każdorazowo historycznie i środowiskowo przyjętej metodologii nauk społecznych.

\section{Teoretyk wygnaniec $w$ realiach polskich}

Tak czy inaczej, w konfrontacji z jednostką wygrywa oczywiście państwo. To ono jest bowiem głównym rozgrywającym w ukazanej tu już grze lub bitwie o hegemonię - wypełnienie pustych form uniwersalności. Skuteczność, z jaką to czyni, zamieniając te formy w "naturalne” kształty rzeczy, odwraca w rezul- 
tacie uwagę obywatela od polityki jako dyskursu konstruktywistycznego. Powściąga tym samym wszelkie zapędy reformatorskie (Badiou, 2010, s. 299300). Konsekwencje tego stanu Judith Butler przedstawia tak oto:

Jeśli nie przeprowadzimy krytyki państwowej przemocy i władzy używanej do skonstruowania podmiotu różnicy kulturowej, ryzykujemy, że nasze roszczenia do wolności zostaną przejęte przez państwo, które z kolei stara się usunąć nam z pola widzenia wszystkie inne powody zaangażowania. Tylko dzięki tego rodzaju krytyce państwa zyskujemy możliwość odnalezienia i potwierdzenia istniejących już sojuszy i punktów styczności z innymi mniejszościami. Tylko wtedy też zaczniemy rozumieć, jak pracuje wpisany w system przymus, by nas rozdzielać i odwracać z dala od krytyki przemocy jako takiej (Butler, 2011, s. 211-212).

Nie ulec pokusie odwracania się od krytyki przemocy państwowej, nie pozostawiać inicjatywy państwu w definiowaniu różnicy kulturowej - a zatem także i podmiotowości/tożsamości w ogóle. Nie ulec złudzeniu, że wszelka podmiotowość - jednostkowa i zbiorowa - może pojawić się i istnieć tylko w ramach państwa, lub, cytując klasyka, można powiedzieć, że jest ona tylko tym, „co mówi o niej władza państwowa” (Hegel, 2002, s. 324). Tożsamości społeczne i kulturowe mają charakter relacyjny - społeczna ontologia przedmiotu składa się z takich właściwości, jak „być pod wpływem czegoś” i „wywoływać coś” (Butler, 2011, s. 226) - i powstają tylko w warunkach zróżnicowania, sporu, antagonizmu. Przyjmując takie założenie, odrzuca się w rezultacie liberalne, racjonalistyczne przekonanie o możliwości osiągnięcia powszechnego konsensusu, tak samo jak i konserwatywną wiarę w ostateczne fundamenty państwa i prawa. Zakłada się za to, że solidarności i sojusze utrzymywane są przez antagonizmy - i dlatego są ciągle otwarte. Stąd i wymagana wrażliwość (składnik świadomości krytycznej) na zapędy państwa w generowaniu zestawów „danych ontologicznych” w zakresie pojęć - pustych znaczących - o których znów wspomina Butler:

W takim przypadku sojusz musi bacznie obserwować metody państwowego przymusu (poczynając od testów dla imigrantów aż po tortury) oraz wszelkie przywołania (zwłaszcza redukujące) takich pojęć, jak podmiot, natura, kultura czy religia, które wytwarzają horyzont ontologiczny, w którym przymus ze strony państwa jawi się jako konieczny i usprawiedliwiony (Butler, 2011, s. 228).

Jak wyglądają tego rodzaju przywołania kategorii ontologicznych, czyli pustych form uniwersalności odwołujących się do transcendentalnych znaczonych, poprzedzających tekst i zamykających dyskurs, albo po prostu tylko symulujących go? Krytyk wygnaniec ujawnia istnienie takich znaczonych sensów, pod- 
miotów/tożsamości, mających znamiona naturalności, istniejących zatem jakoby jeszcze przed powstaniem państwa i prawa. Pokazuje, że praktyki politycznej nie da się oddzielić od praktyki dyskursywnej, że rozum publiczny, także ten naukowy, nie jest żadnym transparentnym nośnikiem znaczeń, że każdy akt komunikacyjny ma konotacje społeczno-polityczne, uwikłany jest w określone relacje władzy pojętej najszerzej jako dominacja, hegemonia jednej grupy ludzi - etnos, płeć, rasa, klasa - nad drugą, wyrażająca się w mechanizmach opresji, przemocy (fizycznej bądź symbolicznej), wykluczenia, marginalizacji...

Spróbujmy zilustrować i prześledzić tego rodzaju praktykę krytyczną, odwołując się tym razem do rodzimego dyskursu politycznego ( $w$ innym miejscu podobny zabieg został przeprowadzony na materiale niemieckim [Hudzik, 2016]). Andrzej Leder, krytyk teoretyk, w opisanej tu wersji wygnańca pisze między innymi:

Problemem III Rzeczpospolitej - podobnie jak jej poprzedniczki - była i jest niezdolność klasy politycznej do znalezienia w obrębie społecznego imaginarium politycznego słów i symboli, znaczących, które włączyłyby poczucie krzywdy we wspólnotę republiki. Nieumiejętność odniesienia się do tych części społeczeństwa, które czują się skrzywdzone i jednocześnie pałają resentymentalnym gniewem. [...] Problem polega więc na tym, że poczucie krzywdy w Polsce nie stworzyło języka politycznego. Owszem, operuje [się] językiem żałobnym, językiem wykluczenia moralnego, językiem odwetu "przywracającego ład moralny”, ale żaden z nich nie stwarza płaszczyzny współistnienia. Politycy, którzy chcieliby do „ludu krzywdy” przemawiać językiem polityki - a jest to język wyrzekający się otwartej konfrontacji w sferze pozasymbolicznej, realnej, a więc wyrzekający się wojny - pozostają dla niego „niemi”. Problem dotyczy zresztą nie tylko polityków. Szeroko rozumiane elity, a więc ci, którzy poprzez komunikację w polu symbolicznym panują nad sposobem nadawania zdarzeniom sensu, nad wzbogacaniem i chronieniem imaginarium, również są zupełnie bezradne.

Ta bezradność zaś zawsze popychała do załatwiania sprawy łatwo - pogardą lub pochlebstwem. Istnieją bowiem dwa proste sposoby poradzenia sobie $\mathrm{z}$ istnieniem skrzywdzonych i pełnych gniewu. Pierwszy polega na pogardliwym piętnowaniu takich stanów ducha, jak nienawiść czy chęć odwetu. Sposób ten zawsze był wybierany przez kręgi - nazwijmy to - liberalne. W Polsce międzywojennej charakterystyczne było dla nich środowisko „Wiadomości Literackich”, a w III RP - „Gazety Wyborczej”. Zakazywanie tego rodzaju przeżyć, napominanie, że czuć się ich nie powinno, wreszcie drwienie $\mathrm{z}$ tych, którzy ich doświadczają, to fundamentalne grzechy tej postawy. Twierdzę, że są to grzechy, nie dlatego, żebym uważał, że dobrze jest czuć nienawiść, ale dlatego, że zaklinaniem ani pouczaniem, a tym bardziej drwiną, nie redukuje się nienawiści. Raczej się ją wzmacnia. W Polsce zawsze było i wciąż jest wielu ludzi, którzy czują się - słusznie czy nie - skrzywdzeni i traktowani nie- 
sprawiedliwie. W związku z tym pragną odwetu. A także języka, który to pragnienie wyraża.

To pragnienie zresztą niekoniecznie jest uświadamiane, częściej ujawnia się w codziennej zawiści, nieżyczliwości, przysłowiowym już braku wzajemnego zaufania, rozpaczliwych aktach samoafirmacji i - jeszcze smutniejszej - autodestrukcji (Leder, 2013, s. 36-37).

Krytyk wygnaniec po tak zwanym zwrocie politycznym (następstwie zwrotu lingwistycznego) w humanistyce nie konstruuje już, tak jak Habermas, po stronie lewicowo-liberalnej, czy Baberowski, prawicowo-konserwatywnej, modelowych, stabilizacyjnych rozwiązań dla podmiotowości politycznej. Przeciwnie, Leder jest otwarty na przygodność samego siebie, na myślenie i komunikowanie nieliniowe, odwracalne, na nieprzejrzystość własnych intencji i własne uwikłanie w język i kulturowe ramy postrzegania świata. Mówi o dominujących językowych artykulacjach uniwersalności, jaką jest poczucie krzywdy, które wykluczają pokrzywdzonych i same ich krzywdzą, odbierając im głos, pouczając ich i pogardzając nimi. Chce przemawiać z miejsca rozdarcia pomiędzy strategią pochlebiania nienawiści a pogardą dla niej, pomiędzy zakazywaniem tego rodzaju uczuć a drwieniem z tych, którzy ich doświadczają, pomiędzy pouczaniem, moralizowaniem, dającym poczucie wyższości (liberalnym elitom), a wściekłością i pragnieniem odwetu pouczanych/skrzywdzonych. Pomiędzy perspektywą analityka współczesnej popkultury a spojrzeniem historyka „odsłaniającego skrytą tkankę przeszłości” (Leder, 2013, s. 19).

Całe to pozycjonowanie się krytyka, jego ulokowanie się w tym punkcie rozdarcia, „pomiędzy”, staje się możliwe z chwilą gdy decyduje się on wziąć na siebie współodpowiedzialność za opisany stan rzeczy publicznych, co z kolei pozwala mu rozpoznać zło także w sobie samym: „Jestem niedoskonały, zrobiłem coś złego" (Leder, 2013, s. 93). To zdaje się moment przełomowy, punkt, w którym może on zacząć myśleć na własny rachunek, dynamicznie i elastycznie, bez uproszczeń, bez dzielenia świata na dobry-zły, który przecina wszelką polemikę i każe ją traktować jako morderczą dla tożsamości (Leder, 2013, s. 93). Dualistyczna perspektywa, oparta na uniwersalistycznych roszczeniach krytyków stabilizatorów polskiego podmiotu politycznego, według Ledera wiąże się między innymi z wyparciem przez niego takich wydarzeń historycznych, jak zniszczenie ziemiaństwa czy zagłada Żydów.

Mowa teoretyka z nieustalonego i chwiejnego miejsca „pomiędzy” nie jest asymilacją do istniejących norm stanowionych przez „kręgi liberalne”, „szeroko rozumiane elity”, „panujące nad sposobem nadawania zdarzeniom sensu” - wprowadza do nich inność: ludzi, którzy czują się skrzywdzeni, bez których te normy nie mają uniwersalnego zasięgu. Krytykowi chodzi o podmiotowość polityczną, 
w której poczucie krzywdy i agresja przemieni się w materiał demokratycznej rywalizacji - w uniwersum symboliczne, które determinuje dziś polityczność, pozwala świadomie kultywować agresję w postaci ucieleśnionych form działania, takich najpewniej jak demonstracja, bojkot czy strajk, wszelkich cielesnych ekspresji politycznych, które nie czynią nikomu krzywdy, nie mogą być manifestacjami nienawiści i toczenia wojny innymi środkami (Butler, 2016, s. 166-167). Leder, typ teoretyka wygnańca, pokazuje $\mathrm{w}$ ten sposób porażkę zastanych norm i całego opartego na nich projektu politycznego, wychodzi poza horyzont przeszłości i teraźniejszości, otwiera dyskurs polityczny na przyszłość, w której te normy mogą ogarniać swym zasięgiem to, czego dzisiaj nie wypowiadają. Nie daje przy tym jednak żadnych gwarancji, co najwyżej nadzieję na zmianę świata, przebudzenie się ze snu, z nieświadomości nieszczęsnej, okrutnej rewolucji, na wzięcie za nią odpowiedzialności, na przezwyciężenie codziennej zawiści, nieżyczliwości.

\section{$\star \star \star$}

Teoretyk polityki, jako wygnaniec, mówi o rzeczywistości politycznej w kategoriach rozprzestrzeniania się znaków, tekstów, dyskursów, imaginariów itd. W sieci tych odniesień to producenci konkretnych dzieł, tekstów, wypowiedzi na własną odpowiedzialność mają rozstrzygać o tym, co chcą z nimi zrobić, co przez nie nagłośnić, wydobyć na światło dzienne, wprowadzić w zakres uniwersalności, a co wykluczyć z niej i przesunąć do strefy cienia. To chcenie to składnik opisanego tu pozycjonowania się teoretyka w stanie rozdarcia między świadomością bycia nieuprawnionym do krytyki, wypadkową świadomości niemożności stotalizowania całego pola politycznego a koniecznością jej prowadzenia: stałego poszerzania tego pola, poszerzania pojęcia uniwersalności. Chcenie, decyzja, wybór jest momentem, który waży nie tyle w sprawie tożsamości teoretyka - kim chce być, na czym zależy mu w życiu, a zatem także i jego przynależności do jakiejś grupy, wspólnoty intelektualnej czy moralnej - ile w sprawie decyzji o zawiązaniu sojuszu/solidarności przeciw przemocy, dominacji, odrzuceniu, upokorzeniu... W sprawie wstrząśnięcia i ruszenia z posad wspólnoty politycznej.

\section{Literatura}

Baberowski, J. (2015a). „Ungesteuerte Einwanderung. Europa ist gar keine Wertegemeninschaft". Frankfurter Allgemeine Zeitung, 14.09.2015.

Baberowski, J. (2015b). „ «Natürlich kann auch ein Analphabet einen Asylgrund haben». Z Jörgem Baberowskim rozmawia Simon Strauss". Frankfurter Allgemeine Zeitung, 20.09.2015. 
Badiou, A. (2010). Byt i zdarzenie, przeł. P. Pieniążek. Kraków: Wydawnictwo Uniwersytetu Jagiellońskiego.

Bauman, Z. (2006). Płynna nowoczesność, przeł. T. Kunz. Kraków: Wydawnictwo Literackie.

Bohman, J. (2003). „Critical Theory as Practical Knowledge: Participants, Observers, and Critics”. W: S.P. Turner, P.A. Roth (eds.). The Blackwell Guide to the Philosophy of the Social Sciences. Oxford: Blackwell.

Brunkhorst, H. (2014). Kritik und kritische Theorie. Baden-Baden: Nomos.

Buksiński, T. (2001). „Doświadczenie w naukach społecznych”. W: T. Buksiński (red.). Doświadczenie. Poznań: Uniwersytet im. Adama Mickiewicza. Wydawnictwo Naukowe Instytutu Filozofii.

Butler, J. (2010). Walczące słowa. Mowa nienawiści i polityka performatywu, przeł. A. Ostolski. Warszawa: Wydawnictwo Krytyki Politycznej.

Butler, J. (2011). Ramy wojny. Kiedy życie godne jest opłakiwania?, przeł. A. Czarnacka, Warszawa: Instytut Wydawniczy Książka i Prasa. Teatr Dramatyczny m.st. Warszawy im. Gustawa Holoubka.

Butler, J. (2016). Zapiski o performatywnej teorii zgromadzeń, przeł. J. Bednarek. Warszawa: Wydawnictwo Krytyki Politycznej.

Dreier, Ch. (2015). „Jörg Baberowski hetzt gegen Flüchtlinge”. World Socialist Web Site, 1.10.2015, https://www.wsws.org/de/articles/2015/10/01/babe-o01.html (dostęp: 2.05.2018).

Dziubka, K. (2017). „Polityczność jako sfera pierwszoosobowych doświadczeń”. W: A. Czajkowski, D. Drałus, L. Sobkowska, M. Wichłacz (red.). Zjawiska polityczne $w$ perspektywie teoretycznej. Księga jubileuszowa dedykowana Profesorowi Andrzejowi W. Jabłońskiemu. Wrocław: Instytut Politologii Uniwersytetu Wrocławskiego.

Giddens, A. (2003). Stanowienie społeczeństwa. Zarys teorii strukturacji, przeł. S. Amsterdamski. Poznań: Zysk i S-ka.

Grant, R.W. (2004). „Political Theory, Political Science, and Politics”. W: S.K. White, J.D. Moon (eds.). What is Political Theory? London: Sage Publications.

Habermas, J. (2002). Teoria działania komunikacyjnego. T. 2: Przyczynek do krytyki rozumu funkcjonalnego, przeł. A.M. Kaniowski. Warszawa: Wydawnictwo Naukowe PWN.

Hegel, G.W.F. (2002). Fenomenologia ducha, przeł. Ś.F. Nowicki. Warszawa: Fundacja Aletheia.

Hudzik, J.P. (2016). „Intelektualiści w sferze publicznej. Konteksty niemieckie”. Studia Philisophica Wratislaviensia, t. XI, z. 2.

Hudzik, J.P. (2017). „Teoria polityki w ruchu”. W: J. Nocoń (red.). Zagadnienia teorii polityki. Gdańsk: Instytut Politologii Uniwersytetu Gdańskiego.

Jabłoński, A.W. (2017). „Instytucjonalne aspekty teorii polityki”. Teoria Polityki, 1.

Laclau, E. (2014). „Tożsamość i hegemonia. Rola uniwersalności w ustanawianiu logiki politycznej”, przeł. S. Królak. W: J. Butler, E. Laclau, S. Žižek. Przygodność, hegemo- 
nia, uniwersalność. Współczesne debaty na lewicy. Warszawa: Wydawnictwo Krytyki Politycznej.

Laclau, E., Mouffe, Ch. (2007). Hegemonia i socjalistyczna strategia. Przyczynek do projektu radykalnej polityki demokratycznej, przeł. S. Królak. Wrocław: Wydawnictwo Naukowe Dolnośląskiej Szkoły Wyższej Edukacji TWP.

Leder, A. (2013). Prześniona rewolucja. Ćwiczenie z logiki historycznej. Warszawa: Wydawnictwo Krytyki Politycznej.

MacDonald, K. (2012). Kultura krytyki. Ewolucjonistyczna analiza zaangażowania Żydów w XX-wieczne ruchy intelektualne i polityczne, przeł. M. Szczubiałka. Warszawa: Aletheia.

Oakeshott, M.J. (2008). O postępowaniu człowieka, przeł. M. Szczubiałka. Warszawa: Wydawnictwo Naukowe PWN.

Sloterdijk, P. (2012). „Teoria krytyczna umarła”, przeł. A. Serafin. Kronos, 3.

Tugendhat, E. (2004). Wykłady o etyce, przeł. J. Sidorek. Warszawa: Oficyna Naukowa.

\section{Streszczenie}

Artykuł ma odpowiedzieć na pytanie, co to jest krytyczna teoria polityki. Autor przedstawia historyczno-genealogiczne uwarunkowania tego podejścia, jego powiązania ze społeczną teorią krytyczną - głównie z koncepcją Habermasa. Rozważa problem uniwersalności teorii, która potrafi sprzeciwić się hegemonicznemu podmiotowi politycznemu, jakim jest państwo, i podważyć fundamenty jego instytucjonalnej stabilności. Jest to pytanie o teorię, która demaskuje umowność tych fundamentów jako dyskursów - językowych sposobów ujmowania rzeczywistości. Na czym miałaby polegać transcendentalność takiej teorii, zdolnej do wyzwalania podmiotów politycznych $\mathrm{z}$ poczucia bezsilności i niesprawiedliwości? Odpowiedzi na te pytania mają być zawarte w portretach dwóch typów krytycznego teoretyka polityki - stabilizatora oraz wygnańca. Przedstawienie i analiza ich adaptacji w autentycznej praktyce dyskursywnej oparte są na przykładach zaczerpniętych są z niemieckiego i polskiego dyskursu politycznego.

Słowa kluczowe: teoria, krytyczna teoria polityki, krytyk stabilizator, krytyk wygnaniec, teoria quasi-transcendentalna, uniwersalność teorii 